\title{
Dipeptidylpeptidase IV and Trypsin-like Enzymatic Degradation of Human Growth Hormone-releasing Hormone in Plasma
}

Lawrence A. Frohman, Thomas R. Downs, Edgar P. Heimer, and Arthur M. Felix

Division of Endocrinology and Metabolism, Department of Internal Medicine, University of Cincinnati College of Medicine, Cincinnati, Ohio 45267; and Department of Peptide Research, Hoffmann-La Roche Inc., Roche Research Center, Nutley, New Jersey 07110

\begin{abstract}
The plasma enzyme responsible for primary proteolytic cleavage of growth hormone-releasing hormone (GRH) at the 2-3 amino acid bond was characterized. Native GRH[GRH(1-44)$\mathrm{NH}_{2}$ and GRH(1-40)-OH], and $\mathrm{COOH}$-terminally shortened fragments [GRH(1-32)- $\mathrm{NH}_{2}$ and $\mathrm{GRH}(1-29)-\mathrm{NH}_{2}$ ] were rapidly cleaved, while $\mathrm{GRH}(2-32)-\mathrm{NH}_{2}$ was not degraded at this site. Moreover, degradation to $\operatorname{GRH}(3-44)-\mathrm{NH}_{2}$ was unaffected by an aminopeptidase inhibitor, indicating that this metabolite was generated from a single step cleavage by a dipeptidylpeptidase (DPP) rather than sequential aminopeptidase cleavages. Conversion to $\mathrm{GRH}(3-44)-\mathrm{NH}_{2}$ was blocked by diprotin A, a DPP type IV (DPP IV) competitive inhibitor. DAmino acid substitution at either position 1 or 2 also prevented hydrolysis, characteristic of DPP IV. Analysis of endogenous plasma GRH immunoreactivity from a human GRH transgenic pig revealed that the major peak coeluted with GRH(3-44)$\mathrm{NH}_{2}$. Native GRH exhibited trypsin-like degradation at the 11-12 position but cleavage at the 12-13 site occurred only with GRH(1-32)- $\mathrm{NH}_{2}$ and GRH(1-29)-NH2. Formation of these metabolites was independent of prior DPP IV hydrolysis but was greatly reduced by trypsin inhibitors. Evaluation of plasma stability of potential GRH super analogues, designed to resist degradation by these enzymes, confirmed that GRH degradation in plasma occurs primarily by DPP IV, and to a lesser extent by trypsin-like enzyme(s).
\end{abstract}

\section{Introduction}

We have recently reported that human growth hormone-releasing hormone (GRH) ${ }^{1}, \mathrm{GRH}(1-44)-\mathrm{NH}_{2}$, is rapidly metabolized by plasma to a biologically inactive fragment lacking the amino-terminal two residues, tyrosine and alanine (GRH(344)- $\mathrm{NH}_{2}$ ) (1). This metabolite exhibits full crossreactivity in GRH RIA systems and its plasma $t_{1 / 2}$ is much greater than that of the native hormone both in vivo and in vitro. As a consequence, measurement of plasma immunoreactive GRH levels

Address correspondence to Dr. Lawrence A. Frohman, Division of Endocrinology and Metabolism, 231 Bethesda Avenue, ML \#547, University of Cincinnati College of Medicine, Cincinnati, OH 45267.

Received for publication 12 October 1988 and in revised form 14 December 1988.

1. Abbreviations used in this paper: DPP, dipeptidylpeptidase; GRH, growth hormone-releasing hormone; IR, immunoreactive; TFA, trifluoroacetic acid.

J. Clin. Invest.

(c) The American Society for Clinical Investigation, Inc. 0021-9738/89/05/1533/08 \$2.00

Volume 83, May 1989, 1533-1540 results in artifactually elevated levels that include primarily the amino-terminally cleaved metabolite, and possibly other immunoreactive GRH fragments, along with much lower levels of native GRH.

The present study was performed to determine the mechanism(s) responsible and the enzyme(s) involved in this process. We specifically addressed the question of whether the cleavage of the two amino-terminal amino acids occurs by sequential steps involving one or more aminopeptidases or by a single step through the action of a dipeptidylpeptidase (DPP), of which four established classes exist (2). For this purpose, we tested GRH analogues designed to be resistant to the action of the putative enzyme(s) as well as specific enzyme inhibitors. In addition, we sought evidence for other metabolic fragments derived from native GRH and GRH analogues.

Although our initial study (1) was performed using synthetic GRH(1-44)- $\mathrm{NH}_{2}$, recent characterization of plasma from a patient with ectopic GRH secretion associated with a carcinoid tumor revealed that the majority of GRH immunoreactivity was in the form of $\mathrm{GRH}(3-40)-\mathrm{OH}$ (3). In the present report we also provide evidence for similar metabolism in another model of GRH hypersecretion, the transgenic hGRH pig.

\section{Methods}

Incubation, extraction, and HPLC of peptides incubated with plasma. Synthetic human GRH(1-44)- $\mathrm{NH}_{2}$, GRH(1-40)-OH, GRH(1-32)$\mathrm{NH}_{2}, \mathrm{GRH}(1-29)-\mathrm{NH}_{2}$ or various analogues were dissolved in $5 \mathrm{mM}$ acetic acid $(10 \mathrm{mg} / \mathrm{ml})$ and added to human plasma in a ratio of $100 \mu \mathrm{g}$ peptide to $1 \mathrm{ml}$ plasma as previously described (1). A $0.25-1.0-\mathrm{ml}$ aliquot was immediately withdrawn, mixed with $0.25 \mathrm{ml} 1 \mathrm{M}$ trifluoroacetic acid (TFA)/ml plasma, and applied to a $C_{18}$ reverse phase Sep-Pak cartridge (Waters Associates, Milford, MA) that had been previously activated with $5 \mathrm{ml}$ each $0.01 \mathrm{M}$ TFA, $80 \%$ acetonitrile in $0.01 \mathrm{M}$ TFA, and $0.01 \mathrm{M}$ TFA. After washing with $5 \mathrm{ml} 0.01 \mathrm{TFA}$, GRH and its fragments were eluted from the cartridge with $2 \mathrm{ml} 80 \%$ acetonitrile in 0.01 M TFA and lyophilized. The remaining plasma containing GRH was incubated at $37^{\circ} \mathrm{C}$ for $60 \mathrm{~min}$ in a shaking water bath at $60 \mathrm{rpm}$, then extracted in the same manner. HPLC was performed on a $250 \times 4.6-\mathrm{mm}$ Vydac $201 \mathrm{TP}$ or $218 \mathrm{TP}$ reverse phase $\mathrm{C}_{18}$ column using a Varian System instrument (model 5020; Varian Associates Inc., Palo Alto, CA). Samples were resuspended in $0.2 \mathrm{ml} 0.01 \mathrm{M}$ TFA, applied to the column that had been previously equilibrated with $0.01 \mathrm{M}$ TFA- $29 \%$ acetonitrile, and eluted isocratically for $10 \mathrm{~min}$, followed by a shallow acetonitrile gradient $(1 \% / 15 \mathrm{~min})$ at a flow rate of $1 \mathrm{ml} / \mathrm{min}$. The elution position for each of the analogues was determined in a preliminary experiment before performing the incubation with plasma. Peptide peaks were detected by absorption at $210 \mathrm{~nm}$ and their areas determined by triangulation. Fractions were collected at 1-min intervals and lyophilized for GRH RIA or amino acid sequence analysis.

RIA of GRH. GRH was measured by a double antibody RIA as previously described $(4,5)$. The assay sensitivity was $3 \mathrm{pg} /$ tube and the intraassay coefficient of variation was $3.9 \%$. 
Peptides, enzyme inhibitors, and other materials. GRH(1-44) $\mathrm{NH}_{2}$, GRH(1-29) $\mathrm{NH}_{2}$, and their analogues were synthesized by the Merrifield solid-phase procedure $(6,7)$ and purified as previously described (1). $\mathrm{GRH}(1-32) \mathrm{NH}_{2}$ and $\mathrm{GRH}(2-32) \mathrm{NH}_{2}$ were generously provided by Dr. J. Rivier and Dr. W. Vale, Peptide Biology Laboratory, Salk Institute, La Jolla, CA. Diprotin A and 1,10-phenanthroline were purchased from Sigma Chemical Co. (St. Louis, MO) and aprotinin (Trasylol) from Mobay Chemical Corp. (Pittsburgh, PA). Heparinized plasma containing Trasylol (500 kallikrein inhibitory units (KIU)/ml) from a transgenic pig expressing the human GRH gene was generously provided by Dr. R. Behringer and Dr. R. Brinster, Laboratory of Reproductive Physiology, University of Pennsylvania School of Veterinary Medicine, Philadelphia, PA.

Amino acid analysis and sequencing. Amino acid analysis of peptide peaks generated from the incubation of GRH with plasma were performed on an instrument using a postcolumn reaction method with fluorescamine (8). Microsequence analysis was carried out on a sequencer (model 470A; Applied Biosystems, Inc. Foster City, CA) (9). PTH-amino acids at each cycle were identified by HPLC (10).

\section{Results}

Incubation of GRH(1-44)- $\mathrm{NH}_{2}$ and carboxy-terminal shortened forms of $G R H$ with human plasma in vitro. As seen in

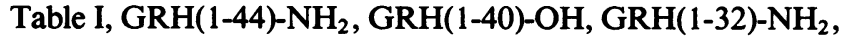
and GRH(1-29)- $\mathrm{NH}_{2}$ were all rapidly cleaved during incubation with plasma at the 2-3 position, as confirmed by sequence analysis of the major metabolite peak. The percent degradation of GRH(1-44)- $\mathrm{NH}_{2}$, GRH(1-32)-NH $\mathrm{NH}_{2}$, and GRH(1-29)$\mathrm{NH}_{2}$, as determined by the area under the curve, was similar, while GRH(1-40)-OH was slightly more stable, confirming our previous observations (1). However, the percentage of the original peptide present as GRH(3-44)- $\mathrm{NH}_{2}$, GRH(3-40)-OH, GRH(3-32)- $\mathrm{NH}_{2}$, and GRH(3-29)- $\mathrm{NH}_{2}$ after the 60-min incubation period was virtually identical. The separation time between the native peptides and the $\operatorname{des}\left(\mathrm{Tyr}^{1} \mathrm{Ala}^{2}\right)$ metabolites also remained relatively constant (10-12 $\mathrm{min}$ ) on our HPLC system irrespective of the length of the parent compound.

Differentiation between aminopeptidase and DPP degradation of GRH. The HPLC absorbance profile from one of the previously discussed peptides, $\mathrm{GRH}(1-32)-\mathrm{NH}_{2}$, is shown in Fig. 1. The top panel shows the ultraviolet (UV) absorbance profile at $210 \mathrm{~nm}$ of $\mathrm{GRH}(1-32)-\mathrm{NH}_{2}$ added to plasma, but without incubation (time 0 ). Incubation of GRH(1-32)- $\mathrm{NH}_{2}$ with plasma resulted in the formation of a new peak (peak $\mathrm{C}$, Fig. 1, middle) with a HPLC retention time of $47 \mathrm{~min}$ as

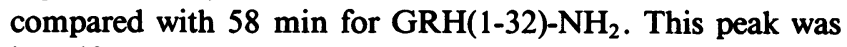
identified as $\mathrm{GRH}(3-32)-\mathrm{NH}_{2}$ by amino acid sequence analysis. Cochromatography of $\mathrm{GRH}(3-32)-\mathrm{NH}_{2}$ together with 10 $\mu \mathrm{g}$ each of synthetic GRH(2-32)- $\mathrm{NH}_{2}$ and GRH(1-32)- $\mathrm{NH}_{2}$ using the same HPLC elution conditions revealed clear resolu- tion of the three peptides (Fig. 1, bottom). However, no peak corresponding to $\mathrm{GRH}(2-32)-\mathrm{NH}_{2}$ could be identified on the HPLC elution profile of GRH(1-32)- $\mathrm{NH}_{2}$ after incubation with plasma (Fig. 1, middle). Other newly generated peaks, designated $A$ at $14 \mathrm{~min}$ and $B$ at $22 \mathrm{~min}$, are discussed later.

The elution profile of GRH(2-32)- $\mathrm{NH}_{2}$ before (top) and after (bottom) incubation with plasma is shown in Fig. 2. No evidence of a peak corresponding to GRH(3-32)- $\mathrm{NH}_{2}$ (Fig. 2, bottom) was seen, and only $56 \%$ of the GRH(2-32)- $\mathrm{NH}_{2}$ was degraded during the 60 -min incubation as compared with $89 \%$ degradation for GRH(1-32)- $\mathrm{NH}_{2}$ (Table I) under the same conditions. However, the formation of other metabolites with shorter retention times (14 and $22 \mathrm{~min}$ ), which were identical to peaks $A$ and $B$ from the degradation of $\mathrm{GRH}(1-32)-\mathrm{NH}_{2}$ (Fig. 1, middle), was unaffected.

The effect of D-amino acid substitution in position 2 was assessed using [D-Ala ${ }^{2}$-GRH(1-29)- $\mathrm{NH}_{2}$. Incubation of this analogue with plasma did not result in the appearance of a peak consistent with [D-Ala ${ }^{2}$-GRH(2-29)- $\mathrm{NH}_{2}$ or GRH(329)- $\mathrm{NH}_{2}$ (Fig. 3, bottom), which, if present, would have eluted at 69 and $68 \mathrm{~min}$, respectively. The degradation of this peptide was only $46 \%$ and earlier eluting peaks at 29 and $40 \mathrm{~min}$ (designated $D$ and $E$ ), which were identical to those observed with unsubstituted GRH(1-29)- $\mathrm{NH}_{2}$ as a substrate (not shown), were again noted (Fig. 3, bottom).

D-Amino acid substitution at position 1, [D-Tyr ${ }^{1}$ ]-GRH(129)- $\mathrm{NH}_{2}$, also prevented the conversion to GRH(3-29)- $\mathrm{NH}_{2}$ during incubation with plasma (not shown). Only $54 \%$ of the peptide was degraded, but two earlier peaks, identical to peaks $\mathrm{D}$ and $\mathrm{E}$ in Fig. 3, were observed.

The effect of several enzyme inhibitors on the degradation of GRH(1-44)- $\mathrm{NH}_{2}$ in plasma were examined next. The metabolism of GRH(1-44)- $\mathrm{NH}_{2}$ in the absence of any enzyme inhibitors is shown in Fig. $4 a$ as reference. After $60 \mathrm{~min}$ of incubation in plasma, $95 \%$ of the GRH(1-44)- $\mathrm{NH}_{2}$ was degraded (Fig. $4 \mathrm{~b}$ ) and two additional peaks, designated $\mathrm{F}$ (8 $\mathrm{min}$ ) and $\mathrm{G}$ (GRH(3-44)- $\left.\mathrm{NH}_{2}, 38 \mathrm{~min}\right)$, were apparent. Incubation of $\mathrm{GRH}(1-44)-\mathrm{NH}_{2}$ with plasma in the presence of 1 mM 1,10-phenanthroline, a chelating agent that inhibits aminopeptidase activity $(2,11)$, is shown in Fig. $4 \mathrm{c}$. Conversion of $\mathrm{GRH}(1-44) \mathrm{NH}_{2}$ to $\mathrm{GRH}(3-44)-\mathrm{NH}_{2}$ (peak $\mathrm{G}$ at 38 min) was not prevented by 1,10 -phenanthroline and the overall degradation of $\mathrm{GRH}(1-44)-\mathrm{NH}_{2}(91 \%)$ was also unaffected. Peak F ( $8 \mathrm{~min})$ was also observed in the presence of the aminopeptidase inhibitor. The effect of diprotin A, a bacterial tripeptide (Ile-Pro-Ile) that competitively inhibits DPP IV (12), is shown in Fig. $4 d$. The presence of $1 \mathrm{mM}$ diprotin A during the plasma incubation greatly reduced the conversion of

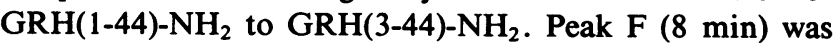

Table I. Effect of GRH Peptide Length on Degradation by Plasma

\begin{tabular}{|c|c|c|c|c|c|}
\hline Parent peptide & $\begin{array}{c}\text { HPLC } \\
\text { retention time }\end{array}$ & $\begin{array}{l}\text { Percent of peptide } \\
\text { degraded at } 60 \mathrm{~min}\end{array}$ & Identity of major metabolite & $\begin{array}{c}\text { HPLC } \\
\text { retention time }\end{array}$ & $\begin{array}{l}\text { Percent of parent peptide present } \\
\text { as metabolite at } 60 \mathrm{~min}\end{array}$ \\
\hline & $\min$ & & & $\min$ & \\
\hline GRH(1-44)-NH & 48 & 92 & GRH(3-44)-NH $\mathrm{NH}_{2}$ & 38 & 28 \\
\hline GRH(1-40)-OH & 52 & 77 & GRH(3-40)-OH & 41 & 26 \\
\hline $\mathrm{GRH}(1-32)-\mathrm{NH}_{2}$ & 58 & 89 & GRH(3-32)- $\mathrm{NH}_{2}$ & 47 & 26 \\
\hline GRH(1-29)-NH & 78 & 94 & GRH(3-29)- $\mathrm{NH}_{2}$ & 66 & 27 \\
\hline
\end{tabular}



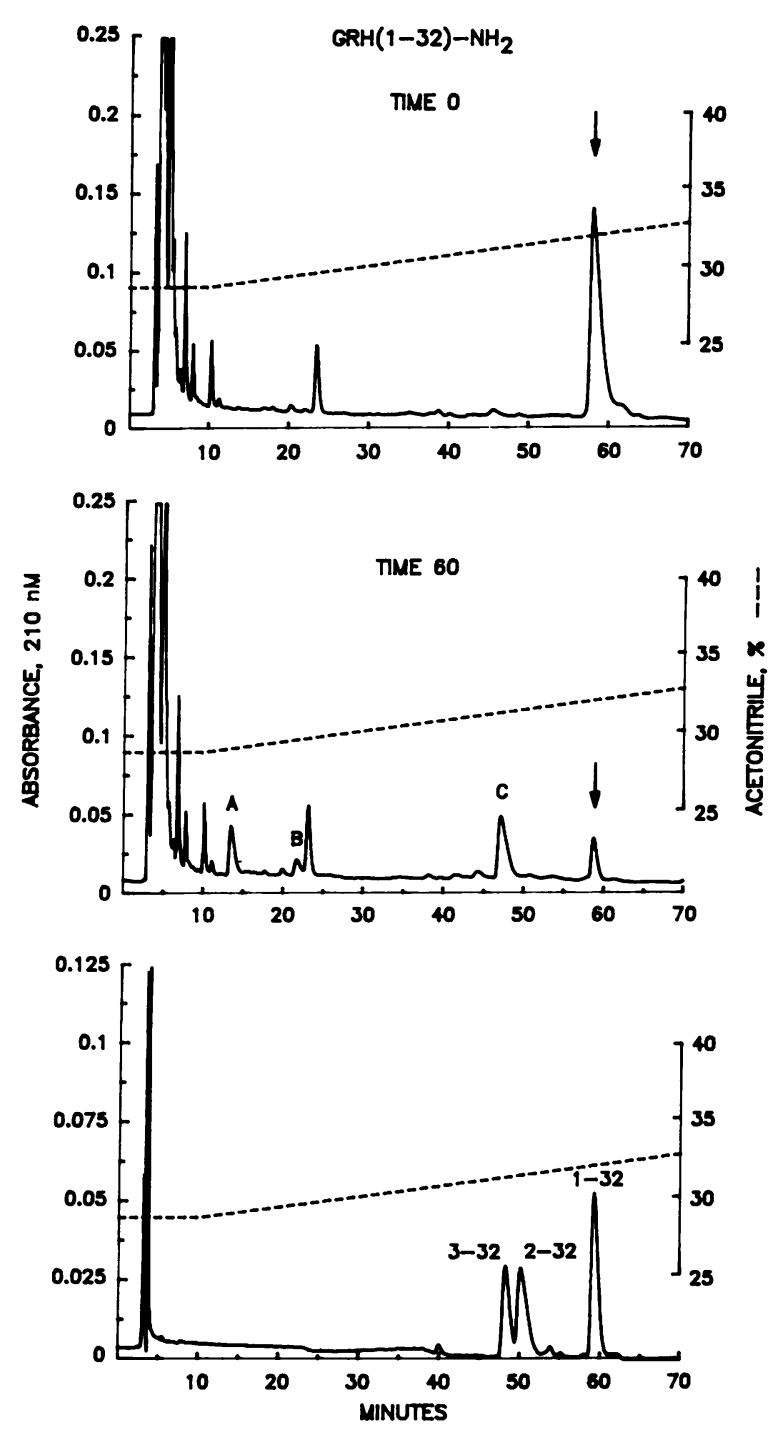

Figure 1. Degradation of GRH(1-32)- $\mathrm{NH}_{2}$ by plasma in vitro (top and middle). $\mathrm{GRH}(1-32)-\mathrm{NH}_{2}$ was added to human plasma and immediately extracted (time 0 , top) or incubated for $60 \mathrm{~min}$ before extraction (time 60 , middle). The extracts were subjected to HPLC as described, and the absorbance patterns at $210 \mathrm{nM}$ are shown. The arrow indicates the elution position of the intact peptide, while GRH metabolites are shown by letter designations. All remaining, unidentified peaks are endogenous plasma proteins. (Bottom) HPLC separation of the peptide from peak C (GRH(3-32)- $\left.\mathrm{NH}_{2}, \sim 10 \mu \mathrm{g}\right)$ applied together with $10 \mu \mathrm{g}$ each of synthetic GRH(1-32)- $\mathrm{NH}_{2}$ and GRH(232)- $\mathrm{NH}_{2} .---$, Acetonitrile gradient.

again observed and the overall degradation of GRH(1-44)$\mathrm{NH}_{2}$ was reduced to $82 \%$.

Characterization of other degradative products of GRH and analogues. Several of the earlier eluting HPLC peaks that were observed after plasma degradation of the previously discussed GRH peptides and analogues (Figs. 1-4) were also subjected to amino acid composition and $\mathrm{NH}_{2}$-terminal sequence analysis. They were identified as $\mathrm{COOH}$-terminal fragments resulting from cleavage at one or both of the basic residues, Arg and Lys, at positions 11 and 12, respectively (Fig. 5). Peptides cleaved at both positions were detected only when the $\mathrm{COOH}$-terminally
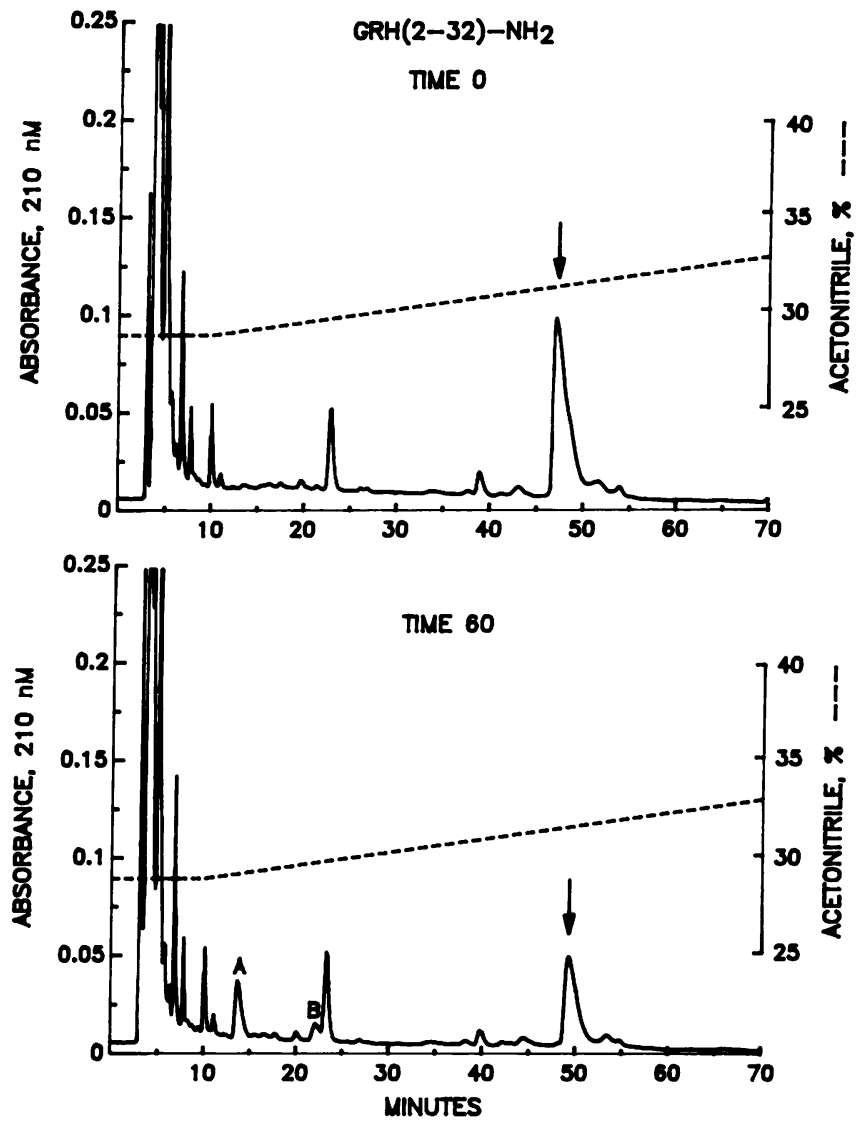

Figure 2. Degradation of GRH(2-32)- $\mathrm{NH}_{2}$ by plasma in vitro. $\mathrm{GRH}(2-32)-\mathrm{NH}_{2}$ was added to human plasma and immediately extracted (time $0, t o p$ ) or incubated for $60 \mathrm{~min}$ before extraction (time 60, bottom). The extracts were subjected to HPLC as described, and the absorbance patterns at $210 \mathrm{nM}$ are shown. The arrow indicates the elution position of the intact peptide, while GRH metabolites are shown by letter designations. All remaining, unidentified peaks are endogenous plasma proteins. -.-, Acetonitrile gradient.

truncated peptides GRH(1-32)- $\mathrm{NH}_{2}$ and GRH(1-29)- $\mathrm{NH}_{2}$ and their analogues were used as substrates.

Peaks A and B (Figs. 1 and 2) were identified as GRH(1232)- $\mathrm{NH}_{2}$ and GRH(13-32)- $\mathrm{NH}_{2}$, respectively, while peaks D and E (Fig. 3) consisted of GRH(12-29)- $\mathrm{NH}_{2}$ and $\mathrm{GRH}(13-$ 29)- $\mathrm{NH}_{2}$, respectively. Only one fragment derived from GRH(1-44)- $\mathrm{NH}_{2}$, peak F (Fig. $4 b$ ), was identified as GRH(12-44)- $\mathrm{NH}_{2}$. The plasma metabolism of GRH(1-40)$\mathrm{OH}$ also resulted in the identification of only GRH(12-40)-OH (not shown). Cleavage at positions 11-12 and 12-13 was independent of prior degradation at the $2-3$ position as seen in Figs. 2,3 , and $4 d$.

Incubation of $\mathrm{GRH}(1-44)-\mathrm{NH}_{2}$ with plasma in the presence of the trypsin inhibitor, Trasylol $(500 \mathrm{KIU} / \mathrm{ml}$ plasma), resulted in much less generation of GRH(12-44)- $\mathrm{NH}_{2}$ (peak $\mathrm{F}$, Fig. 4 e). However, the overall degradation of GRH(1-44)- $\mathrm{NH}_{2}$ was still $82 \%$ and the GRH(3-44)- $\mathrm{NH}_{2}$ peak was 3.3-fold greater than in the absence of the inhibitor. Virtually identical results were observed with another trypsin inhibitor, Foy 007 ( $1 \mathrm{mM}$, not shown). The combination of $1 \mathrm{mM}$ diprotin $\mathrm{A}$ and $500 \mathrm{KIU} / \mathrm{ml}$ Trasylol greatly decreased the generation of both GRH(3-44)- $\mathrm{NH}_{2}$ and $\mathrm{GRH}(12-44)-\mathrm{NH}_{2}$ and reduced the overall degradation of $\mathrm{GRH}(1-44)-\mathrm{NH}_{2}$ to $18 \%$ (Fig. $4 f$ ). 


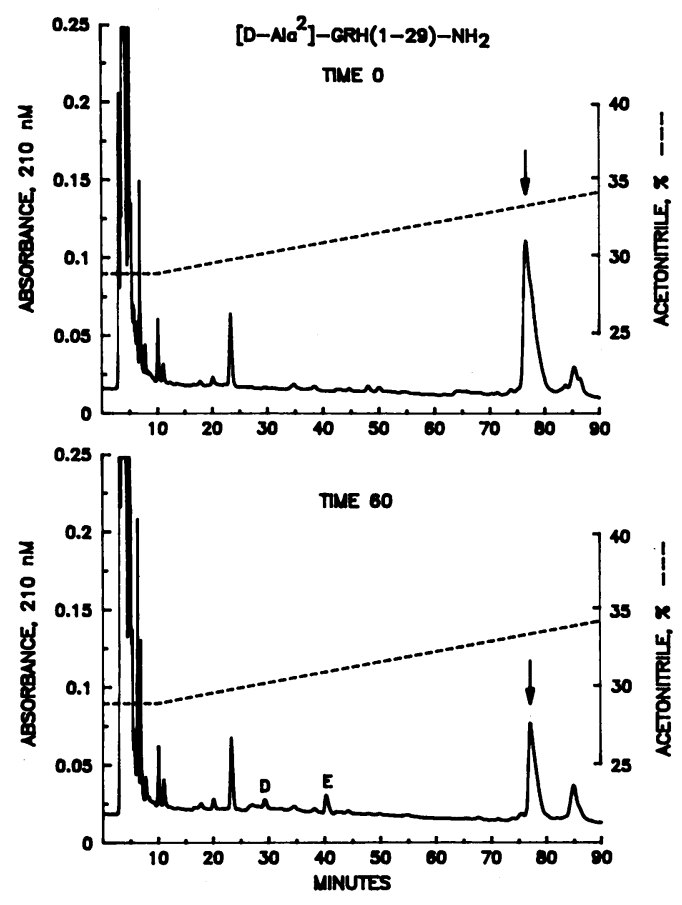

Figure 3. Degradation of [D-Ala $\left.{ }^{2}\right]-G R H(1-29)-\mathrm{NH}_{2}$ by plasma in vitro. See legend to Fig. 2 for details.

Effects of other modifications and substitutions on the degradation of GRH by plasma. Several other modifications of the $\mathrm{NH}_{2}$-terminal tyrosine residue, including deamination or acet- ylation, completely inhibited cleavage at the $2-3$ position (DPP) but did not prevent trypsin-like cleavage at the 11-12 (TL-1) and/or 12-13 (TL-2) positions (Table II). Substitution of $\mathrm{Tyr}^{1}$ with $\mathrm{Phe}^{1}$ or $3-\mathrm{MeHis}^{1}$ did not inhibit generation of any of the metabolites. The replacement of $\mathrm{Gly}^{15}$ with $\mathrm{Ala}^{15}$, resulting in increased $\alpha$-helicial conformation and amphiphilic structure (13), did not reduce DPP hydrolysis, but decreased cleavage by the trypsin-like enzyme(s), resulting in an overall metabolism of only $65 \%$. Concurrent substitution with $\mathrm{Leu}^{27}$, $\mathrm{Asn}^{28}$, designed to reduce loss of biological activity due to oxidation of the native $\mathrm{Met}^{27}$ residue, resulted in slightly more stable forms using 32 or 40 residue analogues with a free $\mathrm{COOH}$-terminus. $\mathrm{N}$-Methylation of $\mathrm{Tyr}^{1}$ in another oxidation-protected analogue, $\left[N-\mathrm{MeTyr}^{1}, \mathrm{Nle}^{27}, \mathrm{Asn}^{28}\right]-\mathrm{GRH}(1-$ 29)- $\mathrm{NH}_{2}$, prevented cleavage by DPP, while trypsin-like hydrolysis was unaffected. $\alpha$-Methylation of $\mathrm{Tyr}^{1}$, however, only partially blocked degradation by DPP. Among the linear GRH analogues, the trisubstituted form, [desNH $\mathrm{NH}_{2} \mathrm{Tyr}^{1}, \mathrm{D}-\mathrm{Ala}^{2}$, $\mathrm{Ala}^{15}$ ]-GRH(1-29)- $\mathrm{NH}_{2}$, was the most stabile (28\% degradation), with complete resistance to DPP cleavage and reduced metabolism by the trypsin-like enzyme(s).

Stabilization of residue 3 (Asp) and 12 (Lys) by cyclization between the $\beta$-carboxyl and $\epsilon$-amino groups (14), in combination with $\mathrm{Ala}^{15}$ substitution, completely inhibited the trypsinlike cleavages and resulted in only very limited degradation by DPP (Table II). Substitution of Asn ${ }^{8}$ with Asp ${ }^{8}$ and subsequent side-chain to side-chain cyclization with Lys ${ }^{12}$ also completely blocked trypsin-like metabolism and reduced DPP cleavage. The further inclusion of $\mathrm{D}-\mathrm{Ala}^{2}$ in this analogue reduced overall degradation to $7 \%$ and no metabolites were seen.

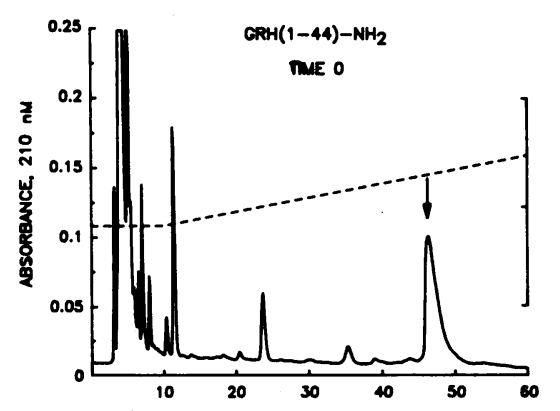

b

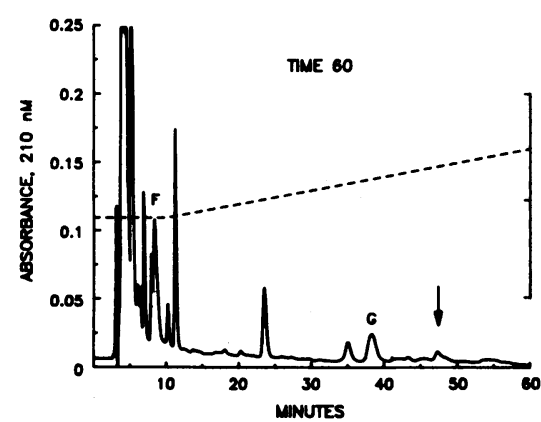

c

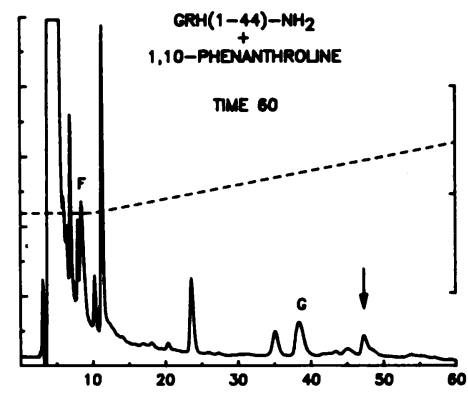

d

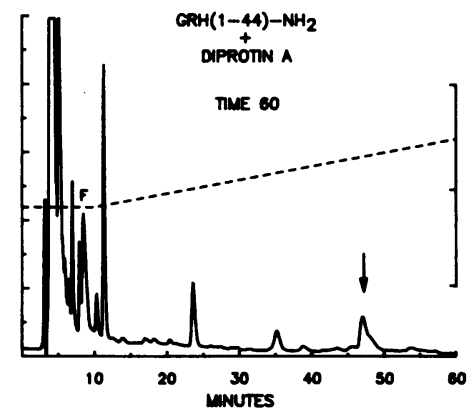

e

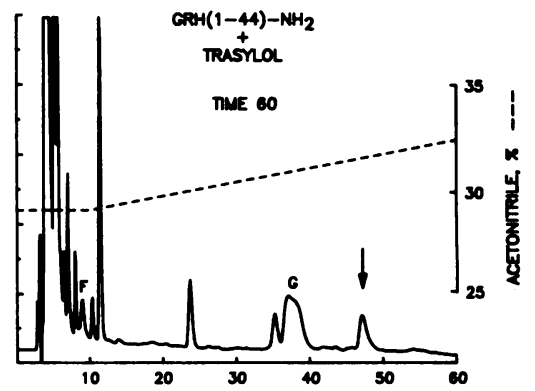

f

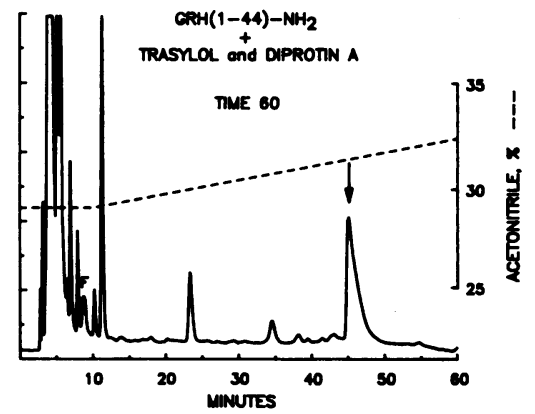

Figure 4. Degradation of GRH(1-44)- $\mathrm{NH}_{2}$ by plasma in vitro in the presence and absence of various protease inhibitors. The absorbance profile of GRH(1-44)- $\mathrm{NH}_{2}$ added to plasma without inhibitors is shown at time $0(a)$ and after a 60 -min incubation $(b)$. $c-f$ show the profiles after a 60-min incubation of GRH(1-44)- $\mathrm{NH}_{2}$ in plasma in the presence of 1,10-phenanthroline $(c)$, diprotin A $(d)$, Trasylol $(e)$, and Trasylol + diprotin $\mathrm{A}(f)$. See legend to Fig. 2 for other details. 


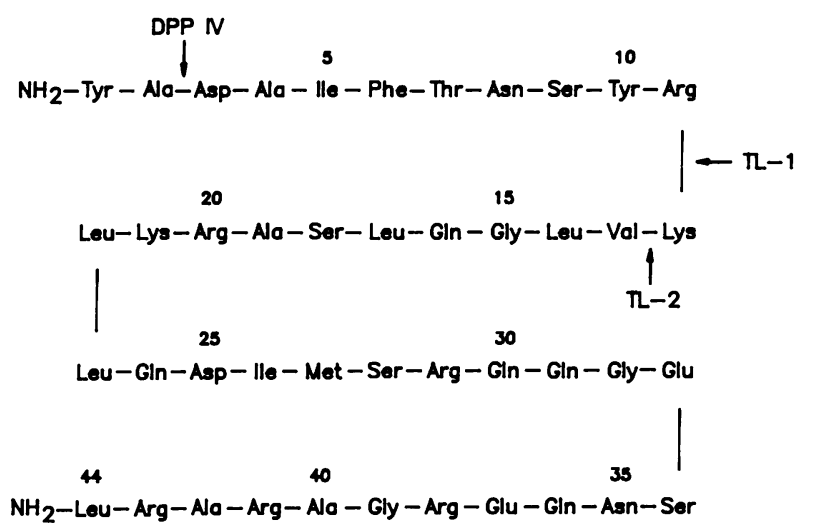

Figure 5. Amino acid sequence of human GRH(1-44)- $\mathrm{NH}_{2}$ indicating the major sites of cleavage (arrows) by plasma enzymes: DPP IV, cleavage by DPP IV at the $2-3$ position; $T L-1$, trypsin-like cleavage at the 11-12 position; and $T L-2$, trypsin-like cleavage at the 12-13 position. TL-2 was seen only with the GRH fragments, (1-32)- $\mathrm{NH}_{2}$ and (1-29)- $-\mathrm{NH}_{2}$ and certain of their analogues.

Characterization of GRH immunoreactivity in plasma from a transgenic pig. The HPLC elution profile of plasma from a hGRH transgenic pig is shown in Fig. 6. The total plasma concentration of immunoreactive (IR) GRH was 5.5 $\mathrm{ng} / \mathrm{ml}$. The largest peak of plasma IR-GRH coeluted with GRH(3-44)- $-\mathrm{NH}_{2}$, while only a small quantity $(\sim 5 \%)$ of the total immunoreactivity eluted in the location of GRH(1-44)$\mathrm{NH}_{2}$. Other small identifiable immunoreactive peaks were observed at 41 (GRH(3-40)-OH), 53 (GRH(1-40)-OH), and 80 min (a possible GRH prohormone, as based on preliminary data [not shown]).

\section{Discussion}

The isolation and sequencing of human GRH has indicated that two forms of the hormone exist in the hypothalamus, GRH(1-44)- $\mathrm{NH}_{2}$ and GRH(1-40)-OH (15). Several studies have demonstrated the potential efficacy of GRH for treatment of certain types of growth deficiency in children (16) as well as accelerated growth and milk production in livestock $(17,18)$. However, the short $t_{1 / 2}(6-10 \mathrm{~min})(1)$ of the native peptides limit their therapeutic usefulness. Since full biological activity of GRH resides within the first 29 amino acids (19, 20 ), development of GRH analogues with enhanced and/or prolonged activity has focused on this $\mathrm{COOH}$-terminally shortened form.

The results of our previous study (1) showed that the primary metabolites of the native GRH peptides in plasma, in vivo and in vitro, were GRH(3-44)- $\mathrm{NH}_{2}$ and GRH(3-40)-OH. These metabolites were more stable than native GRH in plasma, but were virtually completely biologically inactive. The present data demonstrate that $\mathrm{COOH}$-terminally abbreviated fragments of GRH of at least 29 residues were similarly degraded. Moreover, the metabolism of several forms of GRH clearly indicated that this cleavage was due to the action of a DPP rather than the sequential cleavage of the tyrosine and alanine residues by one or more aminopeptidase(s). The degradation of $\mathrm{GRH}(1-44)-\mathrm{NH}_{2}$ to $\mathrm{GRH}(3-44)-\mathrm{NH}_{2}$ was not prevented by 1,10-phenanthroline, an aminopeptidase inhibitor. Additionally, neither [D-Ala ${ }^{2}$ - GRH(1-29)- $\mathrm{NH}_{2}$ nor GRH(2$32)-\mathrm{NH}_{2}$ were degraded by plasma to [D-Ala ${ }^{2}$ - GRH(2-29)$\mathrm{NH}_{2}$ or GRH(3-32)- $\mathrm{NH}_{2}$, respectively, confirming the identification of the degrading enzyme as a DPP.

Currently, four enzymes, and a proposed fifth, make up the

Table II. Effect of Substitutions and/or Modification on the Degradation of GRH Analogues in Plasma

\begin{tabular}{|c|c|c|c|c|}
\hline \multirow[b]{2}{*}{ Peptide } & \multirow[b]{2}{*}{$\begin{array}{l}\text { Percent of peptide } \\
\text { degraded at } 60 \mathrm{~min}\end{array}$} & \multicolumn{3}{|c|}{ Metabolites identified } \\
\hline & & DPP* & ${\mathrm{TL}-1^{\ddagger}}^{\ddagger}$ & TL-2 \\
\hline \multicolumn{5}{|l|}{ Single substituted/ modified analogues } \\
\hline [desNH${ }_{2} \mathrm{Tyr}^{1}$ ]-GRH(1-44)- $\mathrm{NH}_{2}$ & 44 & -11 & +++ & - \\
\hline$\left[\operatorname{des} \mathrm{NH}_{2} \mathrm{Tyr}^{1}\right]-\mathrm{GRH}(1-29)-\mathrm{NH}_{2}$ & 39 & - & +++ & +++ \\
\hline [D-Tyr']-GRH(1-29)-NH $\mathrm{NH}_{2}$ & 54 & - & +++ & +++ \\
\hline$\left[N\right.$-AcTyr']-GRH(1-44)-NH ${ }_{2}$ & 41 & - & +++ & - \\
\hline$\left[\mathrm{Phe}^{1}\right]-\mathrm{GRH}(1-44)-\mathrm{NH}_{2}$ & 91 & +++ & +++ & - \\
\hline [3-MeHis ${ }^{1}$ ]-GRH(1-29)- $\mathrm{NH}_{2}$ & 98 & +++ & +++ & +++ \\
\hline$\left[\mathrm{Ala}^{15}\right]-\mathrm{GRH}(1-29)-\mathrm{NH}_{2}$ & 65 & ++++ & - & + \\
\hline \multicolumn{5}{|l|}{ Multiple substituted/modified analogues } \\
\hline$\left[\mathrm{Ala}^{15}, \mathrm{Leu}^{27}, \mathrm{Asn}^{28}\right]-\mathrm{GRH}(1-32)-\mathrm{OH}$ & 59 & +++ & - & ++ \\
\hline$\left[\mathrm{Ala}^{15}, \mathrm{Leu}^{27}, \mathrm{Asn}^{28}\right]-\mathrm{GRH}(1-40)-\mathrm{OH}$ & 54 & +++ & ++ & - \\
\hline$\left[N-\mathrm{MeTyr}^{1}, \mathrm{Nle}^{27}, \mathrm{Asn}^{28}\right]-\mathrm{GRH}(1-29)-\mathrm{NH}_{2}$ & 60 & - & +++ & +++ \\
\hline$\left[\alpha-\mathrm{MeTyr}^{1}, \mathrm{Ala}^{15}\right]-\mathrm{GRH}(1-29)-\mathrm{NH}_{2}$ & 52 & ++ & + & + \\
\hline$\left[\operatorname{des} \mathrm{NH}_{2} \mathrm{Tyr}^{1}, \mathrm{D}-\mathrm{Ala}^{2}, \mathrm{Ala}^{15}\right]-\mathrm{GRH}(1-29)-\mathrm{NH}_{2}$ & 28 & - & + & + \\
\hline \multicolumn{5}{|l|}{ Cyclic analogues } \\
\hline Cyclo( Asp $\left.^{3}-\mathrm{Lys}^{12}\right)-\left[\mathrm{Ala}^{15}\right]-\mathrm{GRH}(1-29)-\mathrm{NH}_{2}$ & 7 & + & - & - \\
\hline Cyclo( Asp $^{8}-$ Lys $\left.^{12}\right)-\left[\mathrm{Asp}^{8}, \mathrm{Ala}^{15}\right]-\mathrm{GRH}(1-29)-\mathrm{NH}_{2}$ & 12 & + & - & - \\
\hline Cyclo $\left(\mathrm{Asp}^{8}-\mathrm{Lys}^{12}\right)-\left[\mathrm{D}-\mathrm{Ala}^{2}, \mathrm{Asp}^{8}, \mathrm{Ala}^{15}\right]-\mathrm{GRH}(1-29)-\mathrm{NH}_{2}$ & 7 & - & - & - \\
\hline
\end{tabular}

* Cleavage at the 2-3 position by dipeptidylpeptidase IV. ${ }^{\ddagger}$ Cleavage at the 11-12 position by a trypsin-like enzyme. ${ }^{\S}$ Cleavage at the $12-13$ position by a trypsin-like enzyme. "Quantity of metabolite present (UV absorbance) relative to the level observed after plasma degradation of the appropriate unsubstituted GRH form: ++++ , increased $(>125 \%) ;+++$, comparable $(75-125 \%) ;++$, decreased $(50-75 \%) ;+$, decreased $(<50 \%) ;-$, not detectable. 


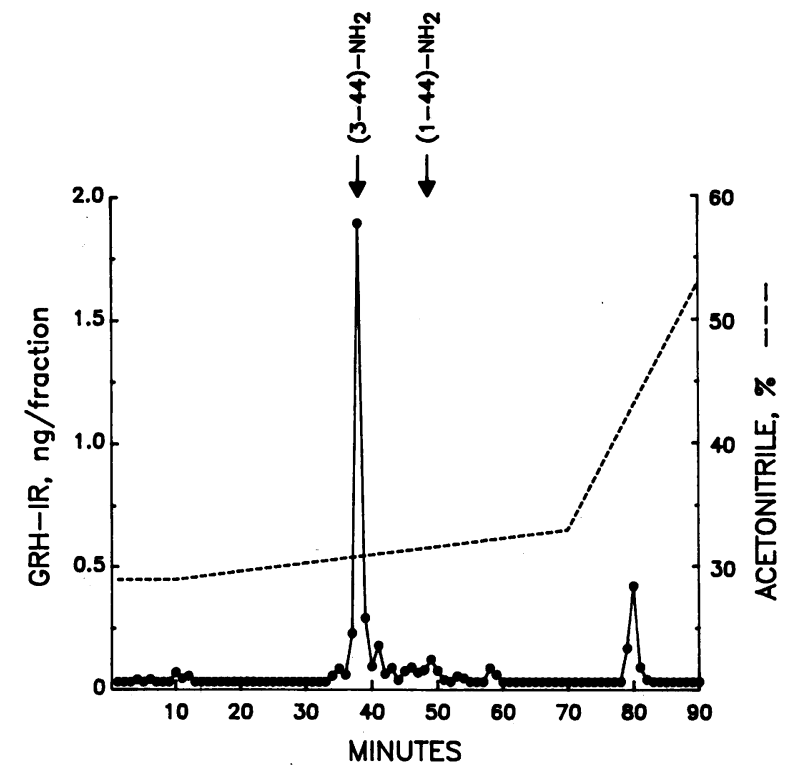

Figure 6. IR-GRH levels in HPLC fractions of a plasma extract from a transgenic pig expressing the hGRH gene. Arrows, elution times of the synthetic GRH standard and metabolite.

DPP subgroup of exopeptide hydrolases $(2,21)$, of which only DPP IV [EC 3.4.14.5] has the necessary substrate specificity and $\mathrm{pH}$ activity optimum (7.8) to hydrolyze GRH in plasma. DPP IV is found in the highest levels as a microvillus membrane-bound enzyme in the kidney, but also as a microsomal membrane-associated and soluble protein in numerous tissues including liver, spleen, skin, jejunum, lung, submaxillary gland, and brain $(11,22-25)$. In addition, DPP IV is present in high concentrations as a soluble enzyme in serum, saliva, and cerebrospinal fluid $(11,22,25,26)$. DPP IV has been classified as a serine protease and exists in a dimeric structure consisting of two identical subunits, each with one active site and a molecular mass of $\sim 130,000 \mathrm{D}(23)$.

DPP IV hydrolysis occurs on the $\mathrm{COOH}$-terminal side of the second amino acid in peptides only if the second residue is proline or alanine $(2,27)$. Its action results in the release of the intact $\mathrm{NH}_{2}$-terminal dipeptide. Though proline is the preferred second residue, peptides with alanine in the penultimate position, especially in conjunction with a bulky, hydrophobic $\mathrm{NH}_{2}$-terminal residue (such as tyrosine), are readily cleaved by DPP IV $(2,27)$. A free amino group on the $\mathrm{NH}_{2}$-terminal residue is also required, demonstrating the exopeptidase property of the enzyme. In addition, DPP IV cleavage is blocked by the substitution of D-amino acid stereoisomers of either the $\mathrm{NH}_{2}$-terminal or penultimate residue. This characteristic is unique among the known DPPs to DPP IV, since DPPs I-III require $\mathrm{L}$-amino acids only in the second position (2).

All of the above modifications of GRH: $\operatorname{desNH}_{2} \mathrm{Tyr}^{1}$, D-Tyr ${ }^{1}$, and D-Ala ${ }^{2}$, completely prevented GRH metabolism by DPP IV to the GRH(3-44)- $\mathrm{NH}_{2}$ or GRH(3-29)- $\mathrm{NH}_{2}$ forms. In addition, cleavage of GRH(1-44)- $\mathrm{NH}_{2}$ to $\mathrm{GRH}(3-44)-\mathrm{NH}_{2}$ was greatly reduced by diprotin $\mathrm{A}$, a competitive inhibitor of DPP IV. In preliminary experiments (not shown) incubation of partially purified DPP IV (from plasma) with GRH(1-44)$\mathrm{NH}_{2}$ resulted in the formation of only GRH(3-44)- $\mathrm{NH}_{2}$. After removal of the $\mathrm{NH}_{2}$-terminal dipeptide, $\mathrm{Tyr}^{1}-\mathrm{Ala}^{2}$, by DPP IV hydrolysis, further DPP IV cleavage at the $\mathrm{Ala}^{4}-\mathrm{Ile}^{5}$ bond has not been observed. Although peptides with an $\mathrm{NH}_{2}$-terminal Asp residue are relatively low activity DPP IV substrates (25), it is possible that the conformation of the primary GRH metabolite could deny DPP IV access to these residues ( $\mathrm{Asp}^{3}$ $\mathrm{Ala}^{4}-\mathrm{Ile}^{5}$ ).

Initial screening of several of the above DPP IV-protected GRH analogues and GRH(3-44)- $\mathrm{NH}_{2}$ showed that these peptides were still metabolized to the extent of $40-50 \%$ during our standard in vitro plasma incubation. Since our original study revealed small amounts of GRH immunoreactivity that eluted near the void volume of our HPLC system, we modified the HPLC conditions to attempt to identify this metabolite(s). A 9-min peak with limited crossreactivity in our GRH RIA, based on the size of its UV absorbance peak, was initially detected after plasma incubation with GRH(1-44)-NH $\mathrm{NH}_{2}$. The metabolite was identified as GRH(12-44)- $\mathrm{NH}_{2}$ and appeared to be the product of a trypsin-like enzymatic hydrolysis at the $\mathrm{Arg}^{11}$-Lys ${ }^{12}$ bond. This metabolite was also observed using DPP IV-protected analogues and GRH(3-44)- $\mathrm{NH}_{2}$ (not shown), suggesting that the trypsin-like cleavage occurs independently of DPP IV degradation. Two different trypsin inhibitors, Trasylol and Foy 007, greatly reduced the formation of the GRH(12-44)- $\mathrm{NH}_{2}$ metabolite.

A third GRH metabolite, detected by UV absorbance only with the GRH(1-32)-NH $\mathrm{NH}_{2}$ and GRH(1-29)- $\mathrm{NH}_{2}$ forms and certain of their analogues, was identified as another trypsinlike cleavage product, GRH(13-32)- $\mathrm{NH}_{2}$ and GRH(13-29)$\mathrm{NH}_{2}$. Inability to detect this form with native GRH peptides cannot be presently explained. However, the amount of GRH(13-32)- $\mathrm{NH}_{2}$ detected was quite small relative to GRH(12-32)- $\mathrm{NH}_{2}$, and only when GRH(1-29)- $\mathrm{NH}_{2}$ and its analogues were used as substrates did the amount of GRH(1329)- $\mathrm{NH}_{2}$ exceed that of GRH(12-29)-NH $\mathrm{NH}_{2}$. Both of these metabolites appear to result from trypsin-like hydrolysis, however, since incubation of GRH(1-29)- $\mathrm{NH}_{2}$ in the presence of Trasylol prevented the formation of $\mathrm{GRH}(12-29)-\mathrm{NH}_{2}$ and GRH(13-29)- $\mathrm{NH}_{2}$, while 1,10-phenanthroline did not stop degradation to GRH(13-29)- $\mathrm{NH}_{2}$ (not shown). Whether these metabolites are formed by successive or independent 11-12 and 12-13 cleavages as well as the number of trypsin-like enzymes involved is unknown.

Other GRH analogues were designed in an attempt to increase biological activity by maximizing amphiphilic structure and extending the $\alpha$-helical region of GRH(1-29)- $\mathrm{NH}_{2}$. Substitution of $\mathrm{Ala}^{15}$ for Gly ${ }^{15}$ created a nearly ideal $\alpha$-helical structure between residues 3-29 and enhanced intrinsic biological activity (28). Degradation of this analogue by both trypsin-like enzymes was greatly diminished. The increased plasma stability observed with additional substitution of $\mathrm{Leu}^{27}, \mathrm{Asn}^{28}$ may be attributed to the use of forms of GRH with a free carboxy terminus, as shown for GRH(1-40)$\mathrm{OH}$. The trisubstituted, DPP IV-protected compound, [desNH ${ }_{2} \mathrm{Tyr}^{1}, \mathrm{D}-\mathrm{Ala}^{2}, \mathrm{Ala}^{15}$ ]-GRH(1-29)- $\mathrm{NH}_{2}$, displayed greater stability than the DPP IV-protected analogues alone due to its resistance to trypsin-like hydrolysis. Cyclization of the $\beta$-carboxyl group of the native $\mathrm{Asp}^{3}$ residue to the $\epsilon$-amino group of the Lys ${ }^{12}$ residue (and $\mathrm{Ala}^{15}$ substitution), produced an analogue that was resistant to both DPP IV and trypsin-like degradation due to the side-chain modifications of residues 3 and 12 that are required for enzyme recognition. Furthermore, side-chain to side-chain cyclization of substituted Asp $^{8}$ with 
Lys $^{12}$ (and Ala ${ }^{15}$ substitution), with or without DPP IV protection (D-Ala ${ }^{2}$, resulted in analogues that displayed nearly complete resistance to both DPP IV and trypsin-like degradation. These observations are explained on the basis of enhancement of $\alpha$-helical structure (28) and side-chain modification of residue 12.

DPP IV hydrolysis of several other bioactive peptides by plasma or partially purified preparations of DPP IV has been previously reported. The opioid peptide, $\beta$-casomorphine $\left(\mathrm{NH}_{2}-\mathrm{Tyr}^{1}\right.$-Pro-Phe-Pro-Gly-Pro-Ile $\left.{ }^{7}-\mathrm{OH}\right)$ is rapidly degraded by three successive DPP IV cleavages and D-amino acid substitutions (Ala or Pro) in position 2 has resulted in analogues with greatly increased stability $(29,30)$. Substance $\mathrm{P}\left(\mathrm{NH}_{2}-\right.$ Arg ${ }^{1}$-Pro-Lys-Pro-Gln-Gln-Phe-Phe-Gly-Leu-Met ${ }^{11}-\mathrm{NH}_{2}$ ) is also sequentially cleaved by DPP IV at the 2-3 and 4-5 sites $(31,32)$. In contrast to GRH metabolites, substance P (3-11)$\mathrm{NH}_{2}$ and (5-11)- $\mathrm{NH}_{2}$ metabolites exhibit intact or increased potency (33) and possibly even different functions, as compared with the parent compound, in several regions of rat brain (34). Many other human brain and gut peptides also contain $\mathrm{NH}_{2}$-terminal sequences that predict susceptibility to DPP IV hydrolysis (though none have yet been reported), including corticotropin-like intermediate lobe protein (ACTH(18-39)), gastic inhibitory polypeptide, gastrin-releasing peptide, neuropeptide $Y$, pancreatic polypeptide, peptidehistidine-methionine, peptide YY, somatomedin C (IGF-I), and somatostatin 28 .

The critical importance of the $\mathrm{NH}_{2}$ terminus for the biological activity of GRH has been documented by several groups $(35,36) . \mathrm{NH}_{2}$-terminal deletions through only the first three residues reduced bioactivity to $<0.02 \%$ of $\mathrm{GRH}(1-44)-\mathrm{NH}_{2}$ (35). Substitution of $\mathrm{Tyr}^{1}$ with residues other than His produced a similar effect (36). Thus, the first superactive GRH analogues were designed by stabilizing the $\mathrm{NH}_{2}$-terminal residues, primarily with D-amino acid substitutions (36-38). The reported increase in the intrinsic activity of some of these analogues in vitro by some investigators $(37,38)$ remains controversial (36). However, the in vivo potency of these peptides was undoubtedly enhanced (37), due in large part to their resistance to DPP IV degradation as we have now shown. More recently, it has been shown by us (39) and others (40) that active GRH analogues that are resistant to both DPP IV and trypsin-like enzymatic degradation exhibit even greater biological potency in vivo than DPP IV-protected analogues alone.

The physiological importance of the rapid degradation of GRH by DPP IV and other enzymes in the regulation of GH secretion is presently unknown. It is conceivable that these enzymes in serum and tissues exert a regulatory role to ensure rapid inactivation of GRH and other bioactive peptides so as to limit their biologic effects to nearby target tissues by a single pass effect, as has been proposed by others (41). The action of these enzymes, however, emphasizes the importance of the development of resistant analogues for potential therapeutic and animal science use. Indeed, we have recently characterized the plasma GRH immunoreactivity in a patient with acromegaly due to an ectopic GRH-producing tumor (3). Plasma IRGRH levels before treatment were nearly $10 \mathrm{ng} / \mathrm{ml}$, but after HPLC separation, intact, native GRH forms were shown to make up only $5-10 \%$ of the total circulating GRH immunoreactivity. In this study, similar results have been shown for the plasma IR-GRH from the human GRH transgenic pig and we have also observed the same pattern in hGRH transgenic mice (42). Thus, continuous circulating levels of intact GRH (as opposed to total IR-GRH) as low as $100-200 \mathrm{pg} / \mathrm{ml}$ may be sufficient to produce persistent $\mathrm{GH}$ hypersecretion. A recent report by Sawano and co-workers has confirmed our results by showing that the major metabolite of $\mathrm{GRH}(1-29)-\mathrm{NH}_{2}$ in plasma is GRH(3-29)- $\mathrm{NH}_{2}$ (43). While we have not observed the secondary $\mathrm{Thr}^{7}-\mathrm{Asn}^{8}$ cleavage that they reported only with the [D-Ala ${ }^{2}$-GRH(1-29)- $\mathrm{NH}_{2}$ analogue, our results do not rule out the possibility of the formation of other minor GRH metabolites.

In conclusion, GRH is rapidly degraded in plasma by DPP IV and trypsin-like enzyme(s) to peptides with virtually no GH-releasing activity. Based on the sites of hydrolysis of GRH by these enzymes, and the structural and conformational requirements for substrate activity, a series of degradation-resistant GRH (super) analogues have been developed for potential clinical and animal science use.

\section{Acknowledgments}

The authors gratefully acknowledge the technical assistance of Jane Withrow.

This work was supported in part by U.S. Public Health Service grant AM-30067.

\section{References}

1. Frohman, L. A., T. R. Downs, T. C. Williams, E. P. Heimer, Y.-C. E. Pan, and A. M. Felix. 1986. Rapid enzymatic degradation of growth hormone-releasing hormone by plasma in vitro and in vivo to a biologically inactive product cleaved at the $\mathrm{NH}_{2}$ terminus. J. Clin. Invest. 78:906-913.

2. McDonald, M. K., and C. Schwabe. 1977. Intracellular exopeptidases. In Proteinases of Mammalian Cells and Tissues. A. J. Barrett, editor. Elsevier/North Holland Biomedical Press, Amsterdam. 311-391.

3. Melmed, S., F. H. Ziel, G. D. Braunstein, T. Downs, and L. A. Frohman. 1988. Medical management of acromegaly due to ectopic production of growth hormone-releasing hormone by a carcinoid tumor. J. Clin. Endocrinol. Metab. 67:395-399.

4. Frohman, L. A., J. L. Thominet, C. B. Webb, M. L. Vance, H. Uderman, J. Rivier, W. Vale, and M. O. Thorner. 1984. Metabolic clearance and plasma disappearance rates of human pancreatic tumor growth hormone-releasing factor in man. J. Clin. Invest. 73:13041311.

5. Frohman, L. A., and T. R. Downs. 1986. Measurement of growth hormone-releasing factor. Methods Enzymol. 124:371-389.

6. Merrifield, R. B. 1963. Solid phase peptide synthesis. I. The synthesis of a tetrapeptide. J. Am. Chem. Soc. 85:2149-2154.

7. Barany, G., and R. B. Merrifield. 1980. Solid-phase peptide synthesis. In The Peptides: Analysis, Synthesis, Biology. Vol. 2. E. Gross and J. Meienhofer, editors. Academic Press, New York. 1-284.

8. Stein, S., and L. Brink. 1982. Amino acid analysis of protein and peptides at the picomole level: the fluorescamine amino acid analyzer. Methods Enzymol. 79:20-25.

9. Pan, Y.-C., J. Wideman, R. Blacher, M. Chang, and S. Stein. 1984. Use of high-performance liquid chromatography for preparing samples for microsequencing. J. Chromatogr. 297:13-19.

10. Hawke, D., P. M. Yuan, and J. E. Shively. 1982. Microsequence analysis of peptides and proteins. Anal. Biochem. 120:302311.

11. Nagatsu, T., T. Sakai, K. Kojima, E. Araki, S. Sakakibara, K. Fukasawa, and M. Harada. 1985. A sensitive and specific assay for dipeptidyl-aminopeptidase II in serum and tissues by liquid chromatography-fluorometry. Anal. Biochem. 147:80-85. 
12. Umezawa, H., T. Aoyagi, K. Ogawa, H. Naganawa, M. Hamada, and T. Takeuchi. 1984. Diprotins A and B, inhibitors of dipeptidyl aminopeptidase IV, produced by bacteria. J. Antibiot. (Tokyo). 37:422-425.

13. Felix, A. M., E. P. Heimer, T. F. Mowles, H. Eisenbeis, P. Leung, T. J. Lambros, M. Ahmad, and C.-T. Wang. 1986. Synthesis and biological activity of novel growth hormone releasing factor analogs. In Peptides. D. Theodoropoulis, editor. W. de Gruyter, Berlin. 481-484.

14. Felix, A. M., C.-T. Wang, E. P. Heimer, and A. Fournier. 1988. Applications of BOP reagent in solid phase synthesis. II. Solid phase side-chain to side-chain cyclizations using BOP reagent. Int. J. Pept. Protein Res. 31:231-238.

15. Ling, N., F. Esch, P. Bohlen, P. Brazeau, W. B. Wehrenberg and R. Guillemin. 1984. Isolation, primary structure, and synthesis of human hypothalamic somatocrinin: growth hormone-releasing factor. Proc. Natl. Acad. Sci. USA. 81:4302-4306.

16. Thorner, M. O., M. L. Vance, W. S. Evans, R. M. Blizzard, A. D. Rogol, K. Ho, D. A. Leong, J. L. C. Borges, M. J. Cronin, R. M. MacLeod, K. Kovacs, S. Asa, E. Horvath, L. A. Frohman, R. Furlanetto, G. Klingensmith, C. Brook, P. Smith, S. Reichlin, J. Rivier, and W. Vale. 1986. Physiological and clinical studies of GRF and GH. Recent Prog. Horm. Res. 42:589-632.

17. Enright, W. J., L. T. Chapin, W. M. Moseley, S. A. Zinn, and H. A. Tucker. 1986. Growth hormone-releasing factor stimulates milk production and sustains growth hormone release in Holstein cows. $J$. Dairy Sci. 69:344-351.

18. Hart, I. C., P. M. E. Chadwick, A. Coert, S. James, and A. D. Simmons. 1985. Effect of different growth hormone-releasing factors on the concentrations of growth hormone, insulin and metabolites in the plasma of sheep maintained in positive and negative energy balance. J. Endocrinol. 105:113-119.

19. Rivier, J., J. Spiess, M. Thorner, and W. Vale. 1982. Characterization of a growth hormone-releasing factor from a human pancreatic islet tumor. Nature (Lond.). 300:276-278.

20. Wehrenberg, W. B., and N. Ling. 1983. In vivo biological potency of rat and human growth hormone-releasing factor and fragments of human growth hormone-releasing factor. Biochem. Biophys. Res. Commun. 115:525-530.

21. Hui, K.-S. 1988. A novel dipeptidyl aminopeptidase in rat brain membranes. J. Biol. Chem. 263:6613-6618.

22. Yoshimoto, T., K. Ogita, R. Walter, M. Koida, and D. Tsuru. 1979. Post-proline cleaving enzyme: synthesis of a new fluorogenic substrate and distribution of the endopeptidase in rat tissues and body fluids of man. Biochim. Biophys. Acta. 569:184-192.

23. Kenny, A. J., A. G. Booth, S. G. George, J. Ingram, D. Kershaw, E. J. Wood, and A. R. Young. 1976. Dipeptidyl peptidase IV, a kidney brush-border serine peptidase. Biochem. J. 155:169-182.

24. Fukasawa, K. M., K. Fukasawa, N. Sahara, M. Harada, Y. Kondo, and I. Nagatsu. 1981. Immunohistochemical localization of dipeptidyl aminopeptidase IV in rat kidney, liver, and salivary glands. J. Histochem. Cytochem. 29:337-343.

25. Nagatsu, T., M. Hino, H. Fuyamada, T. Hayakawa, S. Sakakibara, Y. Nakagawa, and T. Takemoto. 1976. New chromogenic substrates for x-prolyl dipeptidyl-aminopeptidase. Anal. Biochem. 74:466-476.

26. Kato, T., T. Nagatsu, T. Kimura, and S. Sakakibara. 1978. Fluorescence assay of $\mathrm{X}$-prolyl dipeptidyl-aminopeptidase activity with a new fluorogenic substrate. Biochem. Med. 19:351-359.
27. Barth, A., H. Schulz, and K. Neubert. 1974. Untersuchungen zur reinigung und charakterisierung der dipeptidylaminopeptidase IV. Acta Biol. Med. Ger. 32:157-174.

28. Felix, A. M., E. P. Heimer, C.-T. Wang, T. J. Lambros, A. Fournier, T. F. Mowles, S. Maines, R. M. Campbell, B. B. Wegrzynski, V. Toome, D. Fry, and V. S. Madison. 1988. Synthesis, biological activity and conformational analysis of cyclic GRF analogs. Int. J. Pept. Protein Res. 32:441-454.

29. Hartrodt, B., K. Neubert, G. Fischer, U. Demuth, T. Yoshimoto, and A. Barth. 1982. Degradation of $\beta$-casomorphine-5 by proline-specific-endopeptidase (PSE) and post-proline-cleaving enzyme (PPCE):comparative studies of the $\beta$-casomorphine cleavage by dipeptidyl-peptidase IV. Pharmazie. 37:72-73.

30. Kreil, G., M. Umbach, V. Brantl, and H. Teschemacher. 1983. Studies on the enzymatic degradation of $\beta$-casomorphins. Life Sci. 33:137-140.

31. Kato, T., T. Nagatsu, K. Fukasawa, M. Harada, I. Nagatsu, and S. Sakakibara. 1978. Successive cleavage of n-terminal $\mathrm{Arg}^{1}-\mathrm{Pro}^{2}$ and Lys $^{3}-$ Pro $^{4}$ from substance P but no release of $\mathrm{Arg}^{1}-\mathrm{Pro}^{2}$ from bradykinin, by x-Pro dipeptidyl-amino-peptidase. Biochim. Biophys. Acta. 525:417-422.

32. Conlon, J. M., and L. Sheehan. 1983. Conversion of substance P to C-terminal fragments in human plasma. Regul. Pept. 7:335-345.

33. Teichberg, V. I., and S. Blumberg. 1980. Substance $P$ and analogues: biological activity and degradation. Prog. Biochem. Pharmacol. 16:84-94.

34. Nakata, Y., Y. Kusaka, H. Yajima, and T. Segawa. 1981. Active uptake of substance P carboxy-terminal heptapeptide (5-11) into rat brain and rabbit spinal cord slices. J. Neurochem. 37:1529-1534.

35. Guillemin, R., P. Brazeau, P. Bohlen, F. Esch, N. Ling, and W. B. Wehrenberg. 1982. Growth-hormone-releasing factor from a human pancreatic tumor that caused acromegaly. Science (Wash. DC). 218:585-587.

36. Ling, N., A. Baird, W. B. Wehrenberg, N. Ueno, T. Munegumi, T.-C. Chiang, M. Regno, and P. Brazeau. 1984. Synthesis and in vitro bioactivity of human growth hormone-releasing factor analogs substituted at position-1. Biochem. Biophys. Res. Commun. 122:304-310.

37. Lance, V. A., W. A. Murphy, J. Sueiras-Diaz, and D. H. Coy. 1984. Super-active analogs of growth hormone-releasing factor (1-29)amide. Biochem. Biophys. Res. Commun. 119:265-272.

38. Heiman, M. L., M. V. Nekola, W. A. Murphy, V. A. Lance, and D. H. Coy. 1985. An extremely sensitive in vitro model for elucidating structure-activity relationships of growth hormone-releasing factor analogs. Endocrinology. 116:410-415.

39. Mowles, T., P. Stricker, H. Eisenbeis, E. Heimer, A. M. Felix, and P. Brazeau. 1987. Effects of novel GRF analogs on GH secretion in vitro and in vivo. Endocrinol. Jpn. 34:148. (Abstr.)

40. Murphy, W. A., and D. H. Coy. 1988. Potent long-acting alkylated analogs of growth hormone-releasing factor. Pept. Res. 1:36-41.

41. Griffiths, E. C., and J. R. McDermott. 1983. Enzymatic inactivation of hypothalamic regulatory hormones. Mol. Cell. Endocrinol. 33:1-25.

42. Frohman, L. A., T. R. Downs, A. Brar, Y. Kashio, R. Behringer, and R. Brinster. 1988. Characterization of heterogeneous human GH-releasing hormone (hGRH) gene expression by transgenic mice. Endocrine Soc. Annu. Mtg. Abstract 661.

43. Sawano, S., S. Ohashi, H. Masuda, and S. Ozaki. 1988. Degradation and bioactivities of human growth hormone releasing factor(1-29)-amide (GRF-29) and its related peptides. Endocrine Soc. Annu. Mtg. Abstract 264. 